\title{
The additional benefits of energy efficiency investments- a systematic literature review and a framework for categorisation
}

\author{
Josefine Rasmussen (iD
}

Received: 15 September 2015 / Accepted: 17 April 2017 /Published online: 26 May 2017

(C) The Author(s) 2017. This article is an open access publication

\begin{abstract}
Investments in industrial energy efficiency are essential for meeting future energy needs. Nevertheless, the industrial sector's current efforts in energy efficiency investments are insufficient. Additional benefits of energy efficiency investments have been suggested to improve the financial attractiveness of energy efficiency investments. Yet, previous research indicates that not all benefits are included when investment opportunities are evaluated, leading to an underestimation of what a firm will gain from the investment. Additionally, previous research lacks conceptual frameworks for describing these additional benefits at an early stage in the investment process. Moreover, various benefit terms are found in currently existing research, but there are a lack of definitions and distinctions attributed to these terms. Therefore, this paper provides a systematic review on the benefit terms of energy efficiency investments, establishes non-energy benefits as the term most relevant for such investments and provides a new definition of the concept. Further, a new framework for categorising non-energy benefits to enable them to be included during
\end{abstract}

A previous version of this article was originally presented as a conference paper at the ECEEE 2014 Industrial Summer Study and published in the ECEEE 2014 Industrial Summer Study proceedings (Rasmussen J. (2014). Energy-efficiency investments and and the concepts of non-energy benefits and investment behaviour. Proceedings ECEEE Industrial Summer Study - Retool for a Competitive and Sustainable Industry, 733-744).

J. Rasmussen $(\bowtie)$

Division of Business Administration, Department of Management and Engineering, Linköping University, 58183 Linköping,

Sweden

e-mail: josefine.rasmussen@liu.se the investment process is developed, in which the level of quantifiability and time frame of the non-energy benefits are taken into account. Including non-energy benefits in the investment process can make energy efficiency investments more attractive and increase their priority against other investments. Moreover, non-energy benefits can reinforce drivers as well as counterbalance known barriers to energy efficiency investments. Acknowledging non-energy benefits can thus contribute to an increased adoption level for energy efficiency investments.

Keywords Energy efficiency investments · Non-energy benefits $\cdot$ Co-benefits $\cdot$ Ancillary benefits $\cdot$ Literature review. Investment decision-making

\section{Introduction}

The industrial sector alone accounts for approximately $30 \%$ of the final energy use worldwide (IEA 2014a). Investments in industrial energy efficiency are therefore essential for meeting future energy needs. In addition to direct energy savings, improving energy efficiency may yield other benefits, and the use of these additional benefits has been stressed as a motivation for energyefficient technologies (e.g. IEA 2014b; IEA 2012). Cost savings stemming from improved energy efficiency have been found to be a high ranked driving force for energy efficiency investments (De Groot et al. 2001; Thollander and Ottosson 2008), yet cost savings are not the primary driver (Pye and McKane 2000). For energy efficiency investments to appeal to industrial 
firms, previous research has advocated that all financial opportunities should be highlighted, as a means of 'making business sense of energy efficiency' (Pye and McKane 2000, p. 182). Yet, these additional benefits are not acknowledged; 'The full costs and benefits of energy efficiency are not assessed or measured, or are not used to inform decision making' (IEA 2014b, p. 132).

Financial evaluation methods are frequently addressed in the context of investment decision-making for energy efficiency investments, often involving capital budgeting tools such as net present value (NPV) and internal rate of return, as well as other, less sophisticated methods, such as calculating a payback period (e.g. Cooremans 2011; Harris et al. 2000; Thollander and Ottosson 2008). Due to a perceived high risk, such as technical risks, energy efficiency investments are subject to a conservative risk attitude (Harris et al. 2000). The perceived high risk affects the investment criteria firms apply during financial evaluation; stricter requirements on payback periods and other investment criteria are required for energy efficiency investments in comparison to general investments (Cooremans 2012; Qiu et al. 2015). Several researchers have also emphasised the presence of barriers to energy efficiency (e.g. Cagno et al. 2013; Cagno and Trianni 2014; De Groot et al. 2001; Sardianou 2008; Sorrell et al. 2000; Thollander and Ottosson 2008; Venmans 2014). Barriers such as technical risks and costs of potential disruptions in production are commonly discussed in empirical studies as high ranked, alongside lack of access to capital and budget funding, low priority level, other investment priorities, slow return, lack of time and a lack of strategic character (Brunke et al. 2014; Cooremans 2012; De Groot et al. 2001; Hasanbeigi et al. 2010; Sardianou 2008; Thollander and Ottosson 2008; Trianni et al. 2013; Venmans 2014). Hence, despite the potential cost savings, energy efficiency investments are hindered by limited access to capital, a perceived slow return and firms not considering energy to be an important issue. These barriers highlight the importance of illuminating the additional benefits of industrial energy efficiency investments, beyond energy savings.

Two previous studies (Fleiter et al. 2012; Trianni et al. 2014) provide frameworks which seek to encompass the characteristics of energy efficiency investments. Both frameworks acknowledge the additional benefits related to energy efficiency investments: Fleiter et al. (2012) through an explicit category and Trianni et al. (2014) in three attribute categories (environmental, production and implementation). However, there is a lack of frameworks associated with these benefits. One exception is shown in Worrell et al. (2003), who applied the term productivity benefits and proposed a framework for evaluating productivity benefits related to energy efficiency technologies. The framework consists of four steps: first, identify and describe the productivity benefits; second, quantify the previously identified benefits to the extent possible; third, identify all necessary assumptions; and fourth, calculate the cost impacts of the productivity benefits (Worrell et al. 2003). This implies that a first step in the process of quantifying the benefits of energy efficiency is to define and categorise them in a way that can enable quantification. Further research on the additional benefits of energy efficiency is thus necessary, both at the empirical level, i.e. through collecting data, and at a theoretical level, i.e. by developing conceptual frameworks that can facilitate description of these benefits to improve the business case of energy efficiency investments (Cooremans 2015). This paper seeks to contribute to the second proposition, i.e. on a theoretical level. There are several terms used for describing benefits stemming from energy efficiency investments, such as non-energy benefits (e.g. Pye and McKane 2000), multiple benefits (IEA 2014b, 2012), co-benefits (Jakob 2006), indirect benefits (Sauter and Volkery 2013) and productivity benefits (e.g. Worrell et al. 2003). Currently existing research lacks clear definitions and distinctions of the different benefit terms, which implies a need for a systematic review. Such definitions may simplify the inclusion of these benefits in the investment process.

In this paper, three benefit terms, i.e. ancillary benefits, co-benefits and non-energy benefits, are systematically reviewed to establish and define the term most appropriate for an industrial context. Identifying the terminology to be used for benefits in an industrial context can facilitate a more consistent application of the benefit terms, which should appeal both to academia and practitioners. Based on the results of the review, the aim of the paper is further to develop a framework for defining and categorising these benefits of energy efficiency investments to enable more well-informed investment decisions. Additionally, this research aims to provide a framework to be used ex-ante, i.e. early on in the analysis, before the investment decision is made, for which research needs have been stressed previously (Cooremans 2015). Since the additional benefits have the potential to exceed energy savings, it is important to 
study how these additional benefits can be acknowledged in the investment decision-making process to help counterbalance present barriers.

The remainder of the paper is organised as follows. In Section 2, the method of the systematic literature review is described. The results of the literature review are then presented in Section 3. In Section 4, the results of the literature review are discussed further, and a new conceptual framework is developed and presented. Finally, the conclusions of the paper are stated in Section 5, along with the limitations of the study and suggestions for future research.

\section{Systematic review: method}

From the introduction, it is evident that there are several benefit terms in energy efficiency literature. Multiple benefits, used as a collective term by the IEA ${ }^{1}$ (2012), is a term applied in various contexts, such as bioenergy (Abou Kheira and Atta 2009; Kraxner et al. 2003), biogas (Katuwal and Bohara 2009), sustainable development in industry clusters (Nagesha 2008) and building renovation (Martinaitis et al. 2007). This indicates certain dispersion in how the terms are used, and the three terms (i.e. non-energy benefits, co-benefits and ancillary benefits) included in multiple benefits by the IEA (2012) are therefore reviewed individually to establish any differences between these terms. When these potential differences (and similarities) are settled, it may serve as a basis for defining benefits related to industrial energy efficiency. Multiple benefits as discussed by the IEA also include energy benefits, such as energy savings. ${ }^{2}$ Since the emphasis of this paper is on the additional benefits of energy efficiency investments, and which term is most appropriate for an industrial context, the review is limited to co-benefits, non-energy benefits and ancillary benefits.

The method used in this review paper is a systematic literature review. A systematic method can ensure quality of a review since the process then is both replicable and transparent (Tranfield et al. 2003). This includes applying defined search terms and search strings to reduce reviewer bias (Collins and Fauser 2005). To ensure scientific rigorousness of a systematic review, one additional criterion is to describe the literature

\footnotetext{
${ }^{1}$ The International Energy Agency.

${ }^{2}$ See for instance IEA (2012), figure 1, p. 6.
}

search in detail (Okoli and Schabram 2010), which is strived for in this section.

The systematic search of the benefit terms was made using the database Scopus $^{3}$ and sorting the hits by number of citations. The literature search was made during autumn/winter 2013 and checked again during spring 2015. The benefit terms searched for were nonenergy benefits, co-benefits and ancillary benefits, and the search was restricted to only cover the subject area 'Energy' and limited to only include articles and conference papers. The search was set to search in title, abstract and keywords. This resulted in the following final search string:

TITLE-ABS-KEY (“TERM”) AND (LIMIT-TO (SUBJAREA, "ENER")) AND (LIMIT-TO (DOCTYPE, “ar") OR LIMIT-TO (DOCTYPE, “cp")).

The number of hits varied greatly for each term. Table 1 presents a summary of the results of the applied search strings.

When a literature search is restricted to a certain subject area, there is a potential risk of excluding relevant articles or papers. Search strings, such as non-energy benefits of energy efficiency, co-benefits of energy efficiency and so on, were therefore also applied in order to capture any possible relevant findings accidently excluded by the subject area restriction.

When reviewing the articles and conference papers found through the search procedure described above, it appeared that the terms 'indirect benefits' and 'productivity benefits' occasionally are used as synonyms to 'non-energy benefits', and additional searches on these terms were made, which yielded additional articles (Cooremans 2011; Worrell et al. 2003; Boyd and Pang 2000).

To decide whether or not the articles or conference papers should be included, the abstracts were read and analysed. If the articles and conference papers considered any of the benefit terms in a manner that was consistent with the aim of this paper, that is, as additional benefits, they were considered as necessary for the research. Finally, the remaining articles and conference papers were then read in full text. Papers not available online in full text were excluded. This was especially the case for older conference papers. There was an overlap of the included papers on the three benefit terms. The total final sample of the systematic

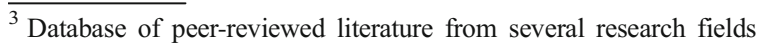
(Elsevier 2014).
} 
Table 1 Summary of search results

\begin{tabular}{lccc}
\hline Term & $\begin{array}{l}\text { Number of } \\
\text { hits }\end{array}$ & $\begin{array}{l}\text { Subject area } \\
\text { energy }\end{array}$ & $\begin{array}{l}\text { Articles/conference } \\
\text { papers }\end{array}$ \\
\hline $\begin{array}{c}\text { Non-energy } \\
\text { benefits }\end{array}$ & 44 & 30 & 26 \\
$\begin{array}{c}\text { Co-benefits } \\
\text { Ancillary } \\
\text { benefits }\end{array}$ & 701 & 166 & 156 \\
\hline
\end{tabular}

literature review on benefit terms was 34 papers, as visualised in Fig. 1 below.

In line with the aim of this paper, the areas in which the different benefit terms are most frequently used, i.e. their main research areas, were identified by reading and analysing the articles and conference papers. This enabled the term most applied in an industrial context to be identified. In addition, the societal level on which the terms were applied was identified using the levels presented by the IEA (2012): individual, sectoral, national and international. Thereafter, the most applied benefit term in an industrial context was identified and explored further. This is described more thoroughly in the next section, Systematic review: results.

\section{Systematic review: results}

When a firm invests in energy efficiency, there are potential benefits both related to and not related to energy savings. These additional benefits can include increased productivity, reduced production costs, higher product quality or improved worker safety (e.g. Pye and McKane 2000). There are, however, several terms discussed in prior research without any clear definitions or distinctions between the definitions used. In this section, the results of the review on the benefit terms 'non-energy benefits', 'ancillary benefits' and 'co-benefits' are presented. The review aims to clarify these terms and decide which benefit term is most adequate to use in relation to industrial energy efficiency investments.

\section{Terminology}

Co-benefits

Based on the number of hits seen in Table 1, the most common benefit term is 'co-benefits'. It is acknowledged as a factor that should be taken into account when discussing the so-called rebound effect (Hertwich 2005), and it has also been used to describe benefits related to energy efficiency investments in the buildings sector (Jakob 2006) and to describe the benefits stemming from $\mathrm{CO}_{2}$ reduction in the buildings sector (ÜrgeVorsatz et al. 2007; Ürge-Vorsatz et al. 2009). The benefits mentioned by Jakob (2006) included, for example, thermal comfort and improved indoor air quality. Tradable White Certificate schemes on an $\mathrm{EU}^{4}$ level and their co-benefits are also mentioned, including, among others, improved competitiveness, increased employment, technological market transformation, air pollution, increased comfort level for households and energy security (Mundaca 2008).

The term co-benefits is most frequently used to describe environmental and health benefits related to reduced $\mathrm{CO}_{2}$ emissions (van Vuuren et al. 2003, 2006; Changhong et al. 2006; He et al. 2010; Malla 2009), climate policy (Aunan et al. 2004; Rypdal et al. 2005), Tradable White Certificate schemes (Mundaca 2008), cleaner production (Mestl et al. 2005), Life Cycle Assessment and environmental impacts (Koornneef et al. 2008; Singh et al. 2012) or bioenergy (Brown et al. 2007; Gan and Yu 2008). With a few exceptions, cobenefits are closely related to the mitigation of $\mathrm{CO}_{2}$ emissions and other environmental impacts. The environmental co-benefits most often mentioned are reduced air pollution, improved local air quality and reduced corrosion of materials, together with the environmental related health benefits (see for example Aunan et al. 2004; Mestl et al. 2005; Koornneef et al. 2008).

\section{Ancillary benefits}

The term 'ancillary benefits' is not applied as often as co-benefits, but when it is used, it is mostly discussed in the same context as co-benefits, and the two terms are used as equivalents (e.g. Mundaca 2008; Jakob 2006; van Vuuren et al. 2006). Lung et al. (2005) also used ancillary benefits as a synonym to non-energy benefits. Benefits commonly stated as ancillary benefits are reduced air pollution (van Vuuren et al. 2006; Rafaj and Kypreos 2007; Xu and Masui 2009), environmental health benefits (Nishioka et al. 2002), employment creation and improved waste control (Bilgen et al. 2007). When evaluating different energy efficiency initiatives,

\footnotetext{
${ }^{4}$ The European Union.
} 


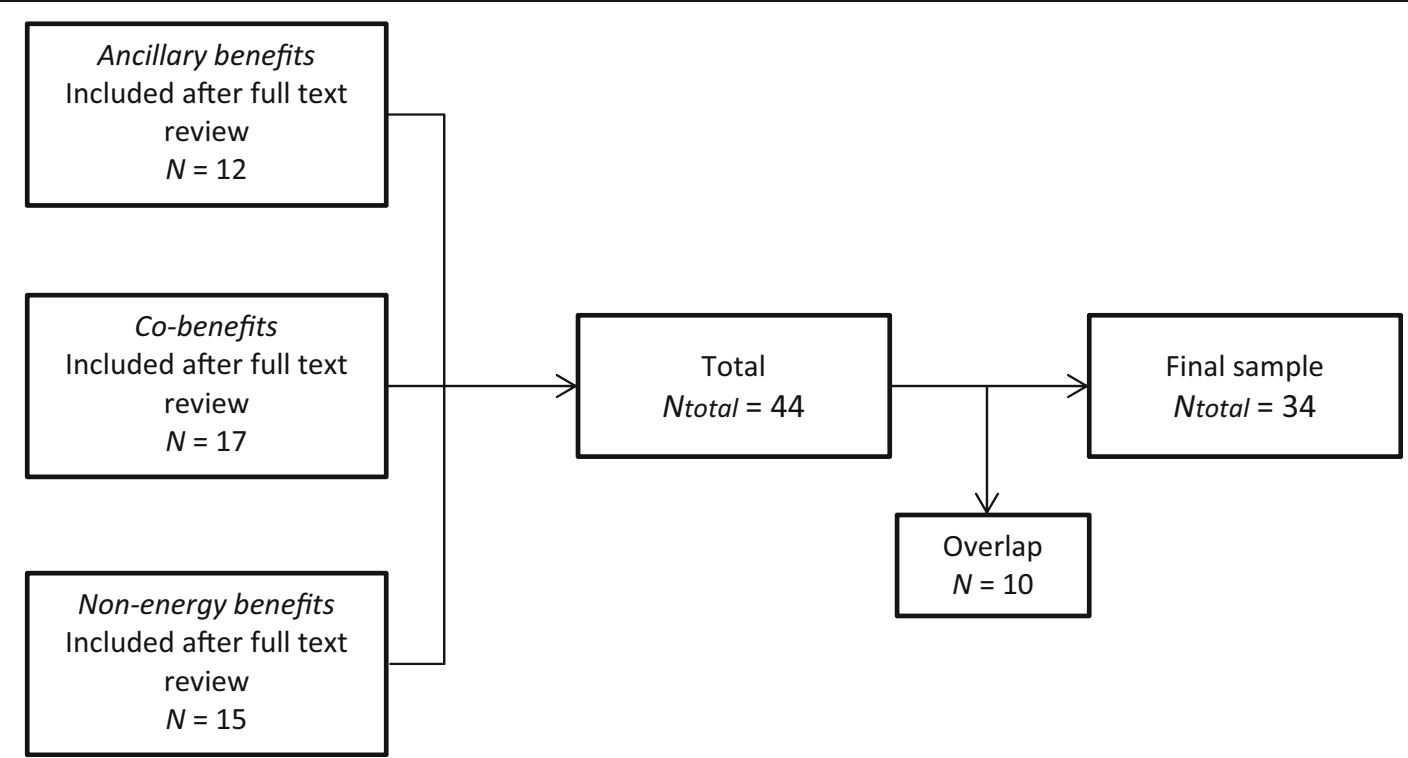

Fig. 1 Final sample systematic review on benefit terms

welfare improvements and positive effects on other resources, such as water supply and employment creation, are also mentioned as ancillary benefits (Neves et al. 2008).

Hence, both co-benefits and ancillary benefits are frequently applied to describe environmental and health benefits. However, a difference which separates ancillary benefits from co-benefits is that ancillary benefits is a term more frequently used in the power generation sector than the term co-benefits (e.g. Rafaj and Kypreos 2007).

Non-energy benefits

Non-energy benefits appear to be used mainly in two areas within the field of energy efficiency: the building (and residential) sector (e.g. Tonn and Peretz 2007) and the industrial sector (e.g. Worrell et al. 2003), respectively. One paper applied a combined approach and studied residential, commercial and industrial nonenergy benefits (Skumatz et al. 2000). Non-energy benefits for the building sector, especially for weatherisation programmes for low-income households, are frequently explored in the literature (e.g. Tonn and Peretz 2007; Schweitzer and Tonn 2003; Skumatz et al. 2000). Categories of different non-energy benefits for this sector are available, for example, the three categories ${ }^{5}$ of utility and ratepayer benefits, societal benefits and participant

\footnotetext{
$\overline{5}$ These three categories were first presented in Skumatz and Dickerson (1997).
}

benefits (Skumatz et al. 2000) or the similar categorisation of ratepayer benefits, household benefits and societal benefits (Schweitzer and Tonn 2003). An additional categorisation of non-energy benefits from a consumer perspective, which can be compared to the participant perspective, is provided by Mills and Rosenfeld (1996), including improved indoor environment, comfort, health and safety; reduced noise; labour and time savings; improved process control; increased amenity or convenience; water savings and waste minimisation and direct and indirect economic benefits from downsizing of equipment. When the potentials and costs of $\mathrm{CO}_{2}$ emissions mitigation are evaluated for the building sector, non-energy benefits are instead divided into five categories, including health effects, ecological effects, economic effects, service provision benefits and social effects (Ürge-Vorsatz et al. 2009). However, even though the names of the categories in the literature differ to some extent, the included non-energy benefits are very similar, including for example fewer illnesses, improved comfort and higher property values.

For the industrial sector, several types of non-energy benefits have been identified, such as reduced maintenance (e.g. Skumatz et al. 2000) and reduced emissions (e.g. Lilly and Pearson 1999). Other non-energy benefits include reduced waste, improved product quality, increased reliability, improved worker safety and improved productivity (Pye and McKane 2000; Mills et al. 2008; Finman and Laitner 2001; Worrell et al. 2003). Few attempts to classify the industrial non- 
energy benefits have been made, but Finman and Laitner (2001) and Worrell et al. (2003) divided them into six categories: waste, emissions, operation and maintenance, production, working environment and other. The benefits in those categories have recently been reorganised into the three categories cost, value and risk (Cooremans 2011). In addition to the nonenergy benefits stated by Worrell et al. (2003), Cooremans (2011) also added four benefits to the risk category, namely legal risks, carbon and energy price risks, disruption of energy supply and commercial risk.

Categorising benefit terms

The additional benefits of improved energy efficiency have previously been categorised according to their societal level - individual, sectoral, national and international (IEA 2012). Benefits observed by individuals, households and firms are considered as individual, whereas the benefits denoted as sectoral are benefits which affect economic sectors, such as the industrial one. On a national level, benefits such as employment creation, energy security and other macroeconomic impacts are mentioned. The mitigation of greenhouse gas emissions and lower energy prices are in turn two examples of benefits occurring on an international level (IEA 2012).

Following the typology used by IEA (2012), there are both similarities and differences between nonenergy benefits, co-benefits and ancillary benefits regarding on which societal level they are observed. This is summarised in Table 2, along with the main research area in which each term is most frequently used. Benefits such as improvements in air quality and its health effects, waste control and/or reduction and competitiveness are examples the three terms have in common. Non-energy benefits are to a larger extent applied in the context of industrial energy efficiency and energy efficiency investments in the residential sector, whereas both co- and ancillary benefits more frequently describe environmental impacts. The benefits categorised as coand ancillary often appear on a national or international level; that is, they are benefits that affect the economy as a whole and not just a specific industry or sector (e.g. air pollution, environmental health benefits, employment creation and energy security). On the contrary, nonenergy benefits can often be considered as sectoral benefits (e.g. industrial) or individual benefits (e.g. households or firms). The benefits mentioned among co-benefits and ancillary benefits are to a large extent inherent, such as reduced emissions, whereas various benefits noted among the non-energy benefits are case specific and dependent on the specific technology. Examples of such benefits are, for instance, improved productivity, reduced amount of raw material or improved work environment. However, inherent benefits such as reduced emissions are also noted among the non-energy benefits.

However, as seen in Table 2, there are exceptions. Co-benefits may occur on an individual level as well, and non-energy benefits may occur on a national level. Energy efficiency programmes aimed at, for example, the residential sector will not only provide non-energy benefits for the individual household but for an entire region as well. ${ }^{6}$ But since these are not the main societal levels in which co-benefits and non-energy benefits occur, they are placed within parentheses in the table. The differences between these terms are further visualised below in Fig. 2.

Benefits occurring mainly on an individual, sectoral and occasionally national level can be recognised from the reviewed literature as non-energy benefits. Benefits occurring on an international, national and sectoral level can in turn be recognised as ancillary or co-benefits. These benefits often have an environmental character, for instance reduced air emissions and health benefits related to environmental improvements (see for example van Vuuren et al. 2006 or Aunan et al. 2004). As can be seen in Fig. 2, there is an overlap between the terms.

For the case of industrial energy efficiency, which mainly concerns the individual (firm) and sectoral level, non-energy benefits appear as the most adequate term to use. Therefore, non-energy benefits will be explored further below.

\section{Exploring and categorising non-energy benefits}

Even though the term 'non-energy benefits' is the most common used for describing the additional benefits stemming from energy efficiency investments, the term and the benefits composing it are not defined, nor categorised, in a clear way. The benefits stated in the literature as industrial non-energy benefits are displayed in Table 3 along with available categorisations.

\footnotetext{
${ }^{6}$ See for example Tonn and Peretz (2007) for the case of state-level benefits.
} 
Table 2 Summary of the main research areas and societal levels for each benefit term

\begin{tabular}{|c|c|c|}
\hline Benefit term & Main research areas & Societal level \\
\hline Co-benefits & $\begin{array}{l}\text { Residential sector, air pollution, climate policy, } \\
\text { bioenergy production, industrial ecology, } \\
\text { health benefits, } \mathrm{h} \\
\text { ousehold energy, cleaner production }\end{array}$ & $\begin{array}{l}\text { - (Individual) } \\
\text { - Sectoral } \\
\text { - National } \\
\text { - International }\end{array}$ \\
\hline Ancillary benefits & $\begin{array}{l}\text { Power systems, bioenergy, wind power, } \\
\text { climate policy, air pollution, health benefits, } \\
\text { wind energy, environmental, } \\
\text { residential sector }\end{array}$ & $\begin{array}{l}\text { - (Individual) } \\
\text { - Sectoral } \\
\text { - National } \\
\text { - International }\end{array}$ \\
\hline Non-energy benefits & $\begin{array}{l}\text { Building and residential sector, weatherisation } \\
\text { programmes, industry, productivity benefits, } \\
\text { environmental taxes, state-level benefits }\end{array}$ & $\begin{array}{l}\text { - Individual } \\
\text { - Sectoral } \\
\text { - (National) }\end{array}$ \\
\hline
\end{tabular}

Note that in addition to the articles and conference papers resulting from the systematic literature review, two reports from non-profit institutions ${ }^{7}$ are included in Table 3 (IEA 2012; Sauter and Volkery 2013). These two reports state additional benefits than those included in Table 3. Benefits not directly related to industrial energy efficiency are excluded from the table, for example, job creation and other macroeconomic effects. The benefits stated in Table 3 are related to industrial energy efficiency and appear on a so-called individual or sectoral level. The same applies to Skumatz et al. (2000) who except for non-energy benefits in the commercial/ industrial sector also covered participant-side non-energy benefits in the residential sector. Since this paper puts emphasis on the benefits related to industrial energy efficiency investments, however, only the results from the former category are included in Table 3 .

As shown in Table 3, there have been few attempts to categorise industrial non-energy benefits. Worrell et al. (2003) and Skumatz et al. (2000) applied categorisations in which the categories were related to the type of benefits, e.g. 'Waste' or 'Production', or to the type of measure, e.g. lighting measures. Cooremans (2011) presented a framework, not only limited to energy efficiency projects, in which non-energy benefits can be categorised according to how they increase value or reduce costs or risks in order to explore the connection between non-energy benefits and competitive advantage, since these three variables are described as 'the three dimensions of competitive advantage'

\footnotetext{
${ }^{7}$ IEA and the IEEP-Institute for European Environmental Policy.
}

(Cooremans 2011, pp. 485-486). Reduced product waste and lowered cooling requirements are examples of benefits categorised as cost benefits, while improved product quality and improved public image are examples of value benefits, i.e. positive impacts on a firm's value proposition. In the risk category, benefits such as reduced emissions and decreased liability are evident (Cooremans 2011). IEA (2012) divided benefits according to economic level, as discussed in the previous section. IEA (2012, p. 25) also addressed the time perspective for non-energy benefits and denote industrial productivity as a short-term benefit. Reduced emissions are another short-term benefit, although it is a long-term effect as well.

There is a variation in how productivity improvements are used in the reviewed literature. Productivity benefits and non-energy benefits have been used interchangeably (Finman and Laitner 2001; Worrell et al. 2003), and ancillary benefits and productivity benefits have been used interchangeably as well (Lung et al. 2005), which implies that the terms can be used as synonyms. On the other hand, productivity benefits are also referred to as a type of non-energy benefit (Worrell et al. 2003; Pye and McKane 2000; Mills et al. 2008; Boyd and Pang 2000), which contradicts using them as synonyms. Productivity is a measure of the ratio of output to input, and in the context of energy efficiency investments, it is possible to observe benefits which are easily quantified and translated into monetary values, such as reduced material costs or increased production (e.g. Pye and McKane 2000). For these benefits, the connection to productivity is more or less straightforward. Yet, there are some benefits, such as improved 
Fig. 2 Benefit terms by societal level

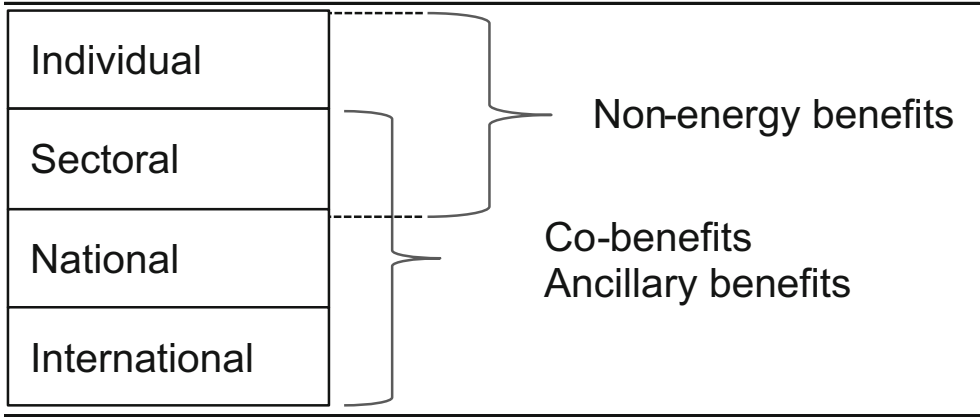

work environments or employee satisfaction, which may affect productivity but are more difficult to observe and even more difficult to translate into monetary values (Worrell et al. 2003). Due to the possible difficulties associated with quantifying these benefits, the relationship between them and productivity cannot be established to the same extent. It is therefore suggested that productivity benefits should be treated as a type of non-energy benefits instead of using these two terms interchangeably as synonyms.

Also worth noting is the geographical focus of the empirical ${ }^{8}$ studies included in Table 3, which are almost exclusively based on US data. Worrell et al. (2003) is an exception; their research studied is based on case study data from various databases from different countries; however, a majority of the data in their study is still from the US, indicating a need for empirical research on non-energy benefits related to industrial energy efficiency investments from other countries and geographical regions.

Besides the lack of frameworks available for categorisation of industrial non-energy benefits, Table 3 also indicates a large variation in the types of benefits indicated as examples of non-energy benefits, such as tangible, quantifiable non-energy benefits (e.g. reduced production costs) (e.g. Pye and McKane 2000), as well as non-energy benefits of a more intangible character, such as improved worker morale (Worrell et al. 2003). Both inherent as well as case-specific benefits are relevant, as discussed in a previous section. The extent to which different non-energy benefits are cited in the included literature is presented in Table 4 below. The non-energy benefits are summarised according to the categorisation by Worrell et al. (2003, p. 488), i.e. by the categories Work Environment, Production,

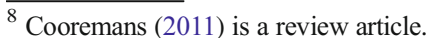

Operations and Maintenance, Waste, Emissions (here Emissions/Environment since the included benefits go beyond reducing emissions) and Other.

According to Table 4, the non-energy benefits reduced emissions, improved product quality, improved productivity, improved reliability and decreased noise are cited most. Summarising the counts for each category, it is evident that non-energy benefits related to production, work environment, and operations and maintenance are the most cited benefits (Table 5 and Fig. 3). Benefits belonging to the category 'Other' also appear to be frequently cited. To account for the number of distinct benefits in each category, the mean value of the categories' citations were calculated, indicating that non-energy benefits belonging to the category 'Other' are cited the least. On the other end, benefits related to emissions and other environmental effects appear to have a higher mean value, even though this category has the lowest count because it includes fewer individual benefits (only five); yet these few benefits are cited frequently, such as reduced emissions.

To summarise, non-energy benefits related to operations and maintenance, production and work environment are the benefits most frequently occurring in the literature, both in absolute counts and on average. Environmental benefits, especially reduced emissions, are also common.

The previous studies included in this review have stressed the importance of quantifying non-energy benefits to show the financial potential of energy efficiency investments (e.g. Pye and McKane 2000; Worrell et al. 2003). In order to fully take non-energy benefits into account when making energy efficiency investments, one approach could therefore be to categorise industrial non-energy benefits into being quantifiable or not quantifiable in monetary terms; however, this approach could lead to the rejection of important, more intangible 
Table 3 Non-energy benefits related to industrial energy efficiency

\begin{tabular}{lll}
\hline Author(s) Mentioned non-energy benefits & $\begin{array}{l}\text { Categorisation } \\
\text { (if any) }\end{array}$
\end{tabular}

\begin{tabular}{cl}
\hline Pye and & Increased productivity, reduced \\
McKane & costs of environmental \\
(2000) & compliance, reduced \\
& production costs (labour, \\
& operations and maintenance, \\
& raw materials), reduced waste \\
& disposal costs, improved \\
& product quality (reduced \\
& scrap/rework costs, improved \\
& customer satisfaction), im- \\
& proved capacity utilisation, \\
& improved reliability, im- \\
& proved worker safety, im- \\
& proved efficiency, reduced \\
emissions, extended life of & equipment, reduced operating \\
time, reduced ancillary oper- & ations, reduced cleaning and \\
& maintenance requirements, \\
increased capacity, decreased & noise
\end{tabular}

Finman and

Laitner

(2001)

Worrell et al.

(2003)

Cooremans

(2011)

Use of waste fuels, reduced product waste, reduced waste water, reduced hazardous waste, materials reduction, reduced dust emissions, reduced $\mathrm{CO}, \mathrm{CO}_{2}, \mathrm{NO}_{\mathrm{x}}, \mathrm{SO}_{\mathrm{x}}$ emissions, reduced need for engineering controls, lowered cooling requirements, increased facility reliability, reduced wear and tear on equipment/machinery, reductions in labour requirements, increased product output/yields, improved equipment performance, shorter process cycle times, improved product quality/purity, increased reliability in production, reduced need for personal protective equipment, improved lighting, reduced noise levels, improved temperature control, improved air quality, decreased liability, improved public image, delaying or reducing capital expenditures, additional space, improved worker morale

Six categories:

1. Waste

2. Emissions

3. Operations and maintenance

4. Production

5. Working environment

6. Other (if any)

Mills et al. (2008)

Lilly and

Pearson

(1999)

et al.

(2000)

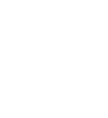

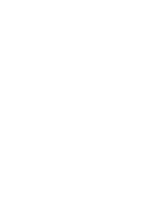

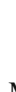


Table 4 Number of times non-energy benefits occur in the reviewed literature

\begin{tabular}{|c|c|c|}
\hline Category & Non-energy benefit & Count \\
\hline $\begin{array}{l}\text { Work } \\
\text { environment }\end{array}$ & $\begin{array}{l}\text { Decreased noise } \\
\text { Improved worker safety } \\
\text { Improved lighting } \\
\text { Improved temperature control } \\
\text { Improved air quality } \\
\text { Reduced need for personal protective } \\
\quad \text { equipment } \\
\text { Improved work environment } \\
\text { Better aesthetics } \\
\text { Reduced glare/eyestrain } \\
\text { Greater comfort } \\
\text { Health }\end{array}$ & $\begin{array}{l}5 \\
4 \\
4 \\
4 \\
4 \\
3 \\
1 \\
1 \\
1 \\
1 \\
1\end{array}$ \\
\hline Production & $\begin{array}{l}\text { Improved productivity } \\
\text { Improved product quality (reduced } \\
\text { scrap/rework costs, improved cus- } \\
\text { tomer satisfaction) } \\
\text { Improved reliability } \\
\text { Increased product output/yields } \\
\text { Improved equipment performance } \\
\text { Shorter process cycle times } \\
\text { Improved capacity utilisation } \\
\text { Improved efficiency } \\
\text { Reduced operating time } \\
\text { Increased capacity } \\
\text { Improved process control }\end{array}$ & $\begin{array}{l}5 \\
5 \\
5 \\
3 \\
3 \\
3 \\
1 \\
1 \\
1 \\
1 \\
1\end{array}$ \\
\hline $\begin{array}{l}\text { Operations and } \\
\text { maintenance }\end{array}$ & $\begin{array}{l}\text { Reduced production costs (labour, } \\
\text { operations and maintenance, raw } \\
\text { materials) } \\
\text { Reduced wear and tear on equipment } \\
\text { and machinery } \\
\text { Reduction in labour requirements } \\
\text { Extended life of equipment } \\
\text { Reduced need for engineering controls } \\
\text { Lowered cooling requirements } \\
\text { Reduced cleaning and maintenance } \\
\text { requirements } \\
\text { Reduced ancillary operations } \\
\text { Better control HVAC measures }\end{array}$ & $\begin{array}{l}4 \\
4 \\
4 \\
3 \\
3 \\
3 \\
2 \\
1 \\
1\end{array}$ \\
\hline Waste & $\begin{array}{l}\text { Use of waste fuels } \\
\text { Reduced product waste } \\
\text { Reduced waste water } \\
\text { Reduced hazardous waste } \\
\text { Materials reduction } \\
\text { Reduced costs of waste disposal } \\
\text { Reduced water losses and bills } \\
\text { More efficient water use }\end{array}$ & $\begin{array}{l}3 \\
3 \\
3 \\
3 \\
3 \\
1 \\
1 \\
1\end{array}$ \\
\hline $\begin{array}{l}\text { Emissions/ } \\
\text { environment }\end{array}$ & $\begin{array}{l}\text { Reduced emissions } \\
\text { Reduced dust emissions } \\
\text { Reduced costs of environmental } \\
\quad \text { compliance } \\
\text { Environmental benefits } \\
\text { Reduced resource use and pollution }\end{array}$ & $\begin{array}{l}5 \\
3 \\
2 \\
1 \\
1\end{array}$ \\
\hline Other & $\begin{array}{l}\text { Improved worker morale/motivation } \\
\text { Decreased liability } \\
\text { Improved public image }\end{array}$ & $\begin{array}{l}4 \\
3 \\
3\end{array}$ \\
\hline
\end{tabular}

Table 4 (continued)

\begin{tabular}{|c|c|c|}
\hline Category & Non-energy benefit & Count \\
\hline & \multirow{2}{*}{$\begin{array}{l}\text { Delaying or reducing capital } \\
\text { expenditures }\end{array}$} & 3 \\
\hline & & 3 \\
\hline & Additional space & 2 \\
\hline & Improved competitiveness & 1 \\
\hline & Reduced legal risks & 1 \\
\hline & Reduced carbon and energy price risks & 1 \\
\hline & Disruption of energy supply & 1 \\
\hline & Reduced commercial risk & 1 \\
\hline & Higher tenant/guest satisfaction & 1 \\
\hline & Increased asset values & 1 \\
\hline & Reduced capital and operating costs & \\
\hline
\end{tabular}

productivity $^{9}$ (Worrell et al. 2003). This indicates that non-energy benefits, both tangible and less tangible, should be acknowledged during the investment decision-making process since they constitute important attributes of energy efficiency investments, in addition to energy savings.

\section{Discussion}

From the review of benefit terms, several conclusions can be drawn. Based on the research area in which the benefit terms are most often applied and the societal level on which they occur, it can be concluded that the term non-energy benefits is the most appropriate to use in the context of industrial energy efficiency investments. Few previous attempts to categorise and define non-energy benefits have been made before, as shown in Table 3. One categorisation frequently cited is the one by Worrell et al. (2003) where benefits are divided into six categories depending on their type-for example, working environment or operation and maintenance. Yet, even if benefits are of the same type, they may still have different characteristics. The need for quantifying non-energy benefits has been stressed in the literature (Mills and Rosenfeld 1996; Pye and McKane 2000; Worrell et al. 2003). Quantification enables benefits to be translated into monetary values and to be included in the financial evaluation, thereby increasing the possibility for energy efficiency investments to meet the pay-

\footnotetext{
${ }^{9}$ The relationship between work environment and productivity has also gained interest outside the energy community. For instance, a previous report based on empirical data from the Nordic countries shows a significant correlation between work environment and productivity (Foldspang et al. 2014). This strengthens improved work environment as an important non-energy benefit.
} 
Table 5 Frequency of citations in the literature of non-energy benefits

\begin{tabular}{lll}
\hline Category & Counts & Mean \\
\hline Work environment & 29 & 2.6 \\
Production & 29 & 2.6 \\
Operations and maintenance & 25 & 2.8 \\
Waste & 18 & 2.3 \\
Emissions/environment & 12 & 2.4 \\
Other & 25 & 1.9 \\
\hline
\end{tabular}

back duration pre-defined by the investor (e.g. Harris et al. 2000). Research has also indicated a lack of access to capital and financial resources as a more prominent reason for not adopting energy efficiency investments at smaller firms (Del Río González 2005). Hence, including non-energy benefits to improve the financial calculation for an energy efficiency investment should be important for all firms, and perhaps even more important for small firms. Therefore, a new definition and categorisation of non-energy benefits is presented in this paper that takes the level of quantifiability into account.

However, there may be substantial benefits that are not easily quantified, such as the often cited improved work environment (Table 5; Fig. 3). In order to acknowledge both tangible and less tangible benefits, using a scale of quantifiability is preferred rather than simply dividing the benefits into being quantifiable versus not quantifiable. This method can prevent benefits not easily quantified, yet still important, from being rejected. In addition to the quantifiability level, the time the benefit is expected to occur should be acknowledged, which has only briefly been addressed in previous research (IEA 2012). IEA (2012, p. 25) touches upon this matter and denotes industrial productivity as a short-term benefit. Other benefits may be more long term, such as improved public image or improved work environment. Non-energy benefits can also occur in a short-term perspective yet still have long-term effects, such as improved productivity. Here, the lifetime of the energy efficiency investment or measure should also be taken into account (Fleiter et al. 2012). The time aspect can contribute to enhance the precision of the calculations. By considering the time in which a benefit will be possible to measure, the risk for under- or overestimating the investment's potential can be decreased. Hence, investment uncertainty can be reduced, which has been found as a negative characteristic for energy efficiency investments (Blyth et al. 2007; De Groot et al. 2001). Including the time perspective can also simplify a future follow-up of the investment. Moreover, a slow return has been identified as a barrier to energy efficiency investments in previous research (Sardianou 2008). Emphasising non-energy benefits occurring already in a short-term perspective can thus work as a means to overcome this barrier.

It is therefore now possible to provide a definition of non-energy benefits, taking into account both the level of quantifiability and time frame: Non-energy benefits can be defined as the benefits related to industrial energy efficiency investments, beside energy savings, that are quantifiable at a varying level and arise in a short-and/or long-term perspective.

\section{A new framework for defining and categorising non-energy benefits}

A lack of conceptual frameworks for describing and categorising non-energy benefits has been identified in previous studies (Cooremans 2015). This paper seeks to contribute to research on energy efficiency investments and non-energy benefits by suggesting a framework for defining and categorising how non-energy benefits of an energy efficiency investment can be classified depending on level of quantifiability and time frame. Since

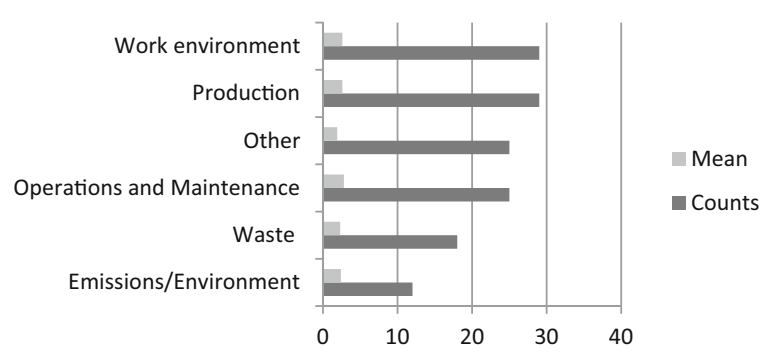

Fig. 3 Bar chart of the frequency of citations of non-energy benefits 
there are a number of so-called softer or unquantifiable non-energy benefits, such as improved public image or improved worker morale, this categorisation will provide a framework which acknowledges the ability of a benefit to be quantified without rejecting those more qualitative and less tangible benefits. IEA (2012) emphasised that energy efficiency improvements, for example by implementing energy efficiency investments, are relatively easy to implement and with rapid effects, both in terms of energy savings and non-energy benefits. Therefore, the time perspective highlights the short-term benefits while still acknowledging the longterm benefits, and further improves the possibilities of making a correct assessment of energy efficiency investments.

In the framework suggested by Worrell et al. (2003), a first step in including non-energy benefits is to 'identify and describe the productivity benefits associated with a given measure' (p. 1088). Moreover, benefits should be described in a detailed and specific manner before the second step: quantification. However, previous studies on non-energy benefits do generally take an ex-post perspective when addressing the benefits, i.e. they are focused on non-energy benefits experienced after implementation. In this paper, an ex-ante perspective has been advocated for, i.e. non-energy benefits should be acknowledged during the investment decision-making process before the investment decision is made to increase the probability for the investment to be adopted and implemented in the first place. The framework proposed in this paper aims to work as a means to identify and describe non-energy benefits $e x-$ ante, and to establish which non-energy benefits are quantifiable in monetary values, and to highlight intangible, yet important, non-energy benefits, as well as their time frame. To this extent, this paper thus serves as a bridge between the first and second step in the framework suggested by Worrell et al. (2003).

The proposed framework is illustrated by a matrix in which the time frame is shown horizontally and the level of quantifiability is shown vertically (Fig. 4 below). The level of quantifiability is denoted on a three-level scale from low to high; the level of quantifiability refers to quantifiability in monetary terms. High refers to those benefits that are easily quantified, Medium represents the benefits which are possible to quantify although not as easily and Low refers to benefits that are difficult or not possible to quantify. The time scale is divided into Short term and Long term, respectively. This way, non- energy benefits with an immediate (short term) effect can be highlighted. If such a benefit is also quantifiable in monetary terms, it can indicate a faster return for the investment than if the non-energy benefit was not included. Since there also are non-energy benefits occurring in a longer time frame as well as short-term benefits continuing over the long term, indicating the time frame for the non-energy benefits is important. For readability, only a limited number of non-energy benefits are included in the matrix to illustrate how a classification can be performed.

It should be noted that the non-energy benefits can, and probably will, differ depending on the energy efficiency investment. Although energy efficiency investments often are discussed as a homogenous group of measures, they differ in their characteristics and hence in terms of non-energy benefits (Fleiter et al. 2012). Energy efficiency investments can differ in terms of distance to the core production activities, and while some investments lead to improved productivity or improved work environment, this is not the case for others. Productivity impacts have been indicated for measures related to electric motor systems but rarely for HVAC systems, and installing heat pipes has indicated a decreased need for operation and maintenance as well as improved work environment (Trianni et al. 2014). The suggested framework and the included non-energy benefits should therefore be considered as illustrative examples and not prescriptive for all energy efficiency investments.

Increased production is an example of a non-energy benefit easily quantified. It occurs within a short-term perspective but also continues over the long run, illustrated when it is denoted again in italics in the upper right of the matrix. On the other end of the scale is Improved public image, which occurs in a long-term perspective and is difficult to quantify. Still, it should be considered as an important non-energy benefit since it increases value and thus contributes to competitive advantage for the firm (Cooremans 2011). Both Improved work environment and Reduced emissions are used as two additional non-energy benefits that would occur both within a short-term perspective and continue over the long term. In a short-term perspective, improvements in work environment, such as reduced noise levels or improved air quality, are easily detected yet difficult to quantify in monetary values, so it is placed in the lower left of the matrix. However, in a longer time perspective, an improved work environment can lead to productivity gains as well as a reduction in sick leaves 
Fig. 4 Framework for classifying industrial non-energy benefits with respect to quantifiability and time frame

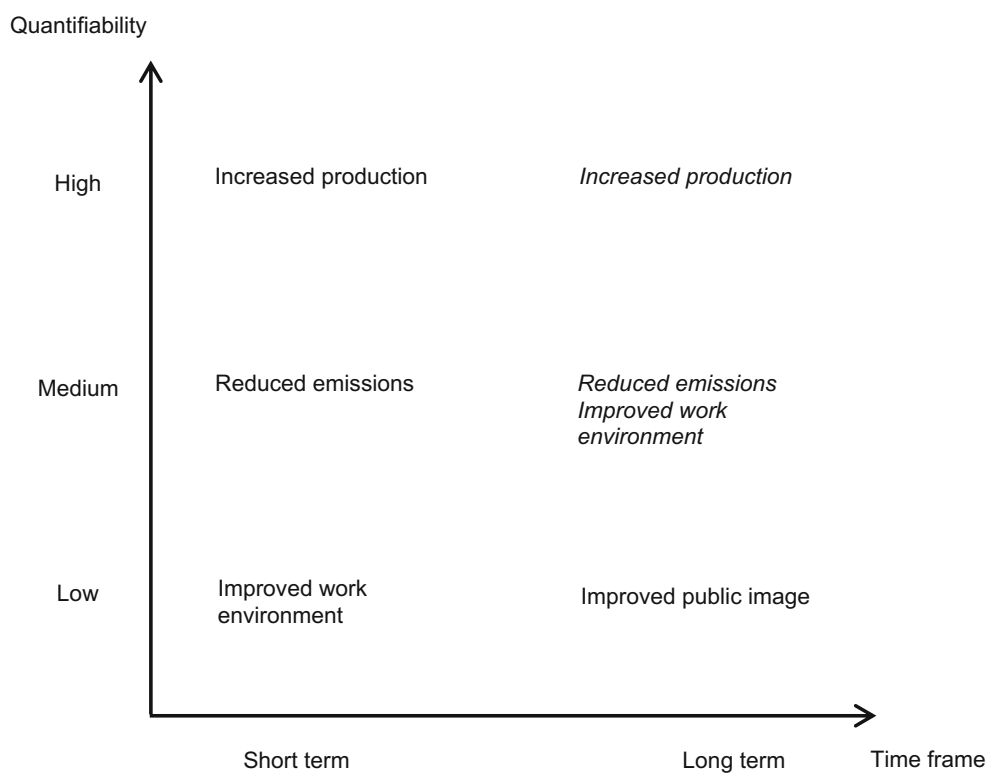

and insurance costs; hence, it is quantifiable (e.g. Cooremans 2015). Improved work environment is placed in the middle of the quantifiability scale due to the difficulties in assigning for instance a reduction in sick leaves to the specific investment, which is necessary if the assessment of the energy efficiency investment is correct. The same reasoning is applicable for the Reduced emissions benefit. Improving energy efficiency is considered an important means in reducing emissions (e.g. IEA 2014a, b), but assigning the reduction in emissions to a specific investment may not be possible, especially not in a long-term perspective; the longer the time frame, the more difficult it is to establish causality between the investment and its potential benefits.

Non-energy benefits can make energy efficiency investments more financially attractive (e.g. Pye and McKane 2000) and have an impact on an investment's payback time (Worrell et al. 2003), which is an economic attribute (Trianni et al. 2014). Hence, as investment characteristics, quantifiable non-energy benefits are therefore important to acknowledge when energy efficiency investments are concerned. However, as described by DeCanio and Watkins (1998, p. 105), 'corporate investment behaviour is considerably more complex than can be described by the bare-bones NPV model of investment'; investment decision making constitute more than financial evaluation. Lumijärvi (1991) discusses the investment decision-making process in terms of subordinates selling an investment project to top management. Four types of arguments are noted, including economic, strategic, non-economic and production technology arguments, ${ }^{10}$ and it is stressed that although the investment must reach certain profitability criteria, this 'is not the most important determinant in the final decision-making' (Lumijärvi 1991, p. 184). In the case of energy efficiency investments, one reason that is often advocated for is energy efficiency investments not being considered as strategically important; instead, they end up being rejected or as a no-decision even though the financial outcome may be positive (Cooremans 2011, 2012; Sandberg and Söderström 2003). The term 'strategicity' has been suggested as an investment characteristic 'to express and describe the strategic character - or strategic nature - of an investment' (Cooremans 2012, p. 503), defined as its impact on a firm's competitiveness, as stated in a previous article (Cooremans 2011). Hence, including other nonbenefits than only the immediate and quantifiable ones is vital. Improved public image, which is used as an example in Fig. 4, is such a benefit that is long term and characterised by a low level of quantifiability, yet contributes to a firm's competitive advantage, i.e. a strategic non-energy benefit (Cooremans 2011).

Previous literature on investment behaviour for energy efficiency investments has placed emphasis on the

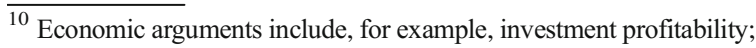
strategic arguments include strategic applicability; non-economic arguments include for instance social factors; and production technology arguments include for example new manufacturing system (Lumijärvi 1991, p. 178).
} 
barriers to energy efficiency. Economic barriers are often ranked high by firms, including barriers such as lack of access to capital, other investment priorities and a slow return (e.g. Cagno et al. 2013; De Groot et al. 2001; Sardianou 2008; Thollander and Ottosson 2008). Nonenergy benefits that are quantifiable and possible to translate into monetary values and arise in a short term can contribute to a higher and faster return than if only energy cost savings are acknowledged, which can counterbalance known barriers and increase the priority level for energy efficiency investments against other investments. Likewise, there are cited non-energy benefits (Table 5; Fig. 3) corresponding to known driving forces, such as improved public image, improved work environment and potential cost savings. Non-energy benefits are thus important investment characteristics related to energy efficiency investments that should be considered ex-ante, i.e. already during the investment process.

\section{Conclusion}

This paper has had two aims: (1) to conduct a systematic review in order to identify the terminology to be used for benefits in an industrial context and (2) to propose a framework for defining and categorising these benefits in a way that enables them to be included during the investment decision-making process, which can further improve the assessment of energy efficiency investments. These aims have been fulfilled through a systematic literature review of the benefit terms ancillary benefits, co-benefits and non-energy benefits. From the results of the review, it is concluded that 'non-energy benefits' is the most adequate benefit term to use for the additional benefits of energy efficiency investments in an industrial context. A definition of non-energy benefits is presented along with a framework for categorising non-energy benefits according to their level of quantifiability and time frame. Non-energy benefits are defined as benefits stemming from an energy efficiency investment, aside from energy savings, that are quantifiable at a certain level and arise in a short- and/or longterm perspective. By applying this framework, firms can define and categorise the non-energy benefits of an energy efficiency investment during the investment decision-making process. The framework allows for heterogeneity of energy efficiency investments and the presence of case-specific non-energy benefits.
It is further suggested that including quantifiable non-energy benefits in the financial evaluation can make energy efficiency investments more financially attractive, as well as increase their priority against other investment opportunities. Also, in addition to emphasising the financial advantage of quantifiable and monetary non-energy benefits, as well as less quantifiable non-energy benefits, this should be acknowledged in the investment decision-making process to promote an energy efficiency investment. Acknowledging non-energy benefits can increase the value of investing today and reinforce driving forces such as a green public image. In addition, acknowledging the non-energy benefits of an energy efficiency investment can act as an offset to existing barriers. In conclusion, acknowledging non-energy benefits during the investment process is an important means to increase the adoption level of energy efficiency investments, contributing to closing the energy efficiency gap. ${ }^{11}$

As for all research studies, this study is subject to limitations. First, a literature review is always characterised by reviewer bias, but the systematic review method applied in this study aims to minimise such bias by the use of predetermined search strings and selection criteria. However, this may lead to narrower coverage of the literature compared to so-called narrative or traditional reviews (Dijkers 2009). There is a risk that relevant literature might have been excluded for not fitting within the search string. Despite this drawback, a systematic approach is preferred since it enables a more replicable, scientific and transparent process (Tranfield et al. 2003, p. 209). A second limitation is that relevant papers and articles had to be excluded due to lack of accessibility. This especially concerned older conference papers, which might have had the implication of a sample skewed to more recent publications. However, this could be considered a rather minor drawback since the research area of additional benefits of energy efficiency is relatively young.

\footnotetext{
${ }^{11}$ Defined as the gap between the potential, optimal and actual level of energy efficiency (e.g. Hirst and Brown 1990). It has been acknowledged in the energy efficiency literature for decades (e.g. Hirst and Brown 1990; Jaffe and Stavins 1994) and remains a matter of high interest (Backlund et al. 2012; Paramonova et al. 2015). The presence of such a gap means that there are energy efficiency technologies not being adopted, despite being cost effective (e.g. Jaffe and Stavins 1994).
} 


\section{Avenues for future research}

The study provides avenues for future research. Existing conceptual frameworks for describing nonenergy benefits are lacking in literature today. The framework proposed herein thus contributes to the research field on non-energy benefits and energy efficiency investments. However, the suggested framework is by no means conclusive. The present framework is limited to two characteristics: level of quantifiability and time frame. Future research is therefore needed to discover whether other aspects could be included in such frameworks. The present framework allows for heterogeneity of energy efficiency investments and their non-energy benefits. One possible avenue for future research is to develop models for assessing non-energy benefits for specific technologies, i.e. whether there are certain characteristics that should be acknowledged for certain technologies, industries, etc. Previous research has also indicated differences in investment behaviour with respect to firm characteristics (e.g. Arvanitis and Ley 2013; DeCanio and Watkins 1998; De Groot et al. 2001; Del Río González 2005). This should also be considered in future research on non-energy benefits. Acknowledging quantifiable non-energy benefits would likely be of higher importance for smaller firms due to a more restricted financial situation for these firms (e.g. Del Río González 2005). Larger firms have also been indicated as more inclined to adopt energy management practices (e.g. Christoffersen et al. 2006; Thollander and Ottosson 2010), which in turn can lead to identifying improvement areas and investment needs.

Further research is also needed to determine whether the adoption rate of energy efficiency investments actually improves when non-energy benefits are included in the investment and evaluation processes. The framework presented here therefore warrants empirical testing. The conclusion that quantifiable non-energy benefits should be included in the financial evaluation gives rise to whether any specific financial evaluation method is better than the other for this purpose, which should be investigated further in future studies.

Additionally, research is needed on the extent to which expected non-energy benefits are realised after implementation, which implies a need for research on how to actually acknowledge the non-energy benefits. To further stimulate firms to consider non-energy benefits, one way could be for suppliers to illuminate and advertise non-energy benefits related to their technologies. Research on the extent to which this is done today as well as how such work could be performed is therefore recommended.

This paper briefly touches upon aspects related to investment decision-making and investment behaviour for energy efficiency investments. The research on investment decision-making is very limited within this empirical context; a vast amount of the research on these issues within the energy efficiency field has been focused on the barriers to energy efficiency. Further research is therefore advocated for where a starting point could be a systematic literature review on these concepts. To the author's best knowledge, such a review does not exist at this point.

Acknowledgements This paper has been financed by the Swedish Energy Agency and the Department for Management and Engineering at Linköping University. I would like to thank Mikael Ottosson and Henrik Nehler for useful comments during the process. I also wish to express my gratitude to the panel leaders of Panel 6. Business models to improve industrial energy efficiency, global perspective at ECEEE Industrial Summer Study 2014 for reviewing and commenting on the conference paper which preceded this paper.

\section{Compliance with ethical standards}

Conflict of interest The author declares that there is no conflict of interest.

Open Access This article is distributed under the terms of the Creative Commons Attribution 4.0 International License (http:// creativecommons.org/licenses/by/4.0/), which permits unrestricted use, distribution, and reproduction in any medium, provided you give appropriate credit to the original author(s) and the source, provide a link to the Creative Commons license, and indicate if changes were made.

\section{References}

Abou Kheira, A. A., \& Atta, N. M. M. (2009). Response of Jatropha curcas L. to water deficit: yield, water use efficiency and oilseed characteristics. Biomass and Bioenergy, 33(10), 1343-1350.

Arvanitis, S., \& Ley, M. (2013). Factors determining the adoption of energy-saving technologies in Swiss firms: an analysis based on micro data. Environmental and Resource Economics, 54(3), 389-417.

Aunan, K., Fang, J., Vennemo, H., Oye, K., \& Seip, H. M. (2004). Co-benefits of climate policy-lessons learned from a study in Shanxi, China. Energy Policy, 32(4), 567-581. 
Backlund, S., Thollander, P., Palm, J., \& Ottosson, M. (2012). Extending the energy efficiency gap. Energy Policy, 51, 392396.

Bilgen, S., Keles, S., \& Kaygusuz, K. (2007). The role of biomass in greenhouse gas mitigation. Energy Sources, Part A: Recovery, Utilization and Environmental Effects, 29(13), $1243-1252$.

Blyth, W., Bradley, R., Bunn, D., Clarke, C., Wilson, T., \& Yang, M. (2007). Investment risks under uncertain climate change policy. Energy Policy, 35(11), 5766-5773.

Boyd, G. A., \& Pang, J. X. (2000). Estimating the linkage between energy efficiency and productivity. Energy Policy, 28(5), 289-296.

Brown, B. B., Yiridoe, E. K., \& Gordon, R. (2007). Impact of single versus multiple policy options on the economic feasibility of biogas energy production: swine and dairy operations in Nova Scotia. Energy Policy, 35(9), 4597-4610.

Brunke, J. C., Johansson, M., \& Thollander, P. (2014). Empirical investigation of barriers and drivers to the adoption of energy conservation measures, energy management practices and energy services in the Swedish iron and steel industry. Journal of Cleaner Production, 84, 509-525.

Cagno, E., \& Trianni, A. (2014). Evaluating the barriers to specific industrial energy efficiency measures: an exploratory study in small and medium-sized enterprises. Journal of Cleaner Production, 82, 70-83.

Cagno, E., Worrell, E., Trianni, A., \& Pugliese, G. (2013). A novel approach for barriers to industrial energy efficiency. Renewable and Sustainable Energy Reviews, 19, 290-308.

Changhong, C., Bingyan, W., Qingyan, F., Green, C., \& Streets, D. G. (2006). Reductions in emissions of local air pollutants and co-benefits of Chinese energy policy: a Shanghai case study. Energy Policy, 34(6), 754-762.

Christoffersen, L. B., Larsen, A., \& Togeby, M. (2006). Empirical analysis of energy management in Danish industry. Journal of Cleaner Production, 14, 516-526.

Collins, J. A., \& Fauser, B. J. M. (2005). Balancing the strengths of systematic and narrative reviews. Human Reproduction Update, 11(2), 103-104.

Cooremans, C. (2011). Make it strategic! Financial investment logic is not enough. Energy Efficiency, 4(4), 473-492.

Cooremans, C. (2012). Investment in energy efficiency: do the characteristics of investments matter? Energy Efficiency, 5(4), 497-518.

Cooremans, C. (2015). Competitiveness benefits of energy efficiency: a conceptual framework. ECEEE Summer Study Proceedings, 123-131.

De Groot, H. L. F., Verhoef, E. T., \& Nijkamp, P. (2001). Energy saving by firms: decision-making, barriers and policies. Energy Economics, 23(6), 717-740.

DeCanio, S. J., \& Watkins, W. E. (1998). Investment in energy efficiency: do the characteristics of firms matter? Review of Economics and Statistics, 80(1), 95-107.

Del Río González, P. (2005). Analysing the factors influencing clean technology adoption: a study of the Spanish pulp and paper industry. Business Strategy and the Environment, 14, $20-37$.

Dijkers, M. P. J. M. (2009). The value of "traditional" reviews in the era of systematic reviewing. American Journal of Physical Medicine \& Rehabilitation, 88, 423-430.
Elsevier. (2014). http://www.elsevier.com/online-tools/scopus. Accessed 20140218.

Finman, H., \& Laitner, J. A. (2001). Industry, energy efficiency and productivity improvements. Proceedings ACEEE Summer Study on Energy Efficiency in Industry, 1, 561-570.

Fleiter, T., Hirzel, S., \& Worrell, E. (2012). The characteristics of energy-efficiency measures - a neglected dimension. Energy Policy, 51, 502-513.

Foldspang, L., Mark, M., Rants, L. L., Hjort, R. L., LangholzCarstensen, C., Poulsen, M. O., Johansson, U., Ahonen, G., \& Aasnæss, S. (2014). Working environment and productivity. A register-based analysis of Nordic enterprises. TemaNord, 2014, 546 Nordic Council of Ministers.

Gan, L., \& Yu, J. (2008). Bioenergy transition in rural China: policy options and co-benefits. Energy Policy, 36(2), 531540.

Harris, J., Anderson, J., \& Shafron, W. (2000). Investment in energy efficiency: a survey of Australian firms. Energy Policy, 28(12), 867-876.

Hasanbeigi, A., Menke, C., \& du Pont, P. (2010). Barriers to energy efficiency improvement and decision-making behavior in Thai industry. Energy Efficiency, 3, 33-52.

He, K., Lei, Y., Pan, X., Zhang, Y., Zhang, Q., \& Chen, D. (2010). Co-benefits from energy policies in China. Energy, 35(11), 4265-4272.

Hertwich, E. G. (2005). Consumption and the rebound effect: an industrial ecology perspective. Journal of Industrial Ecology, 9(1-2), 85-98.

Hirst, E., \& Brown, M. (1990). Closing the efficiency gap: barriers to the efficient use of energy. Resources, Conservation and Recycling, 3, 267-281.

IEA. (2012). Spreading the net: the multiple benefits of energy efficiency improvements. Insights Series 2012. Paris: OECD/IEA.

IEA. (2014a). World energy investment outlook. Paris: $\mathrm{OECD} / \mathrm{IEA}$.

IEA. (2014b). Capturing the multiple benefits of energy efficiency. Paris: OECD/IEA.

Jaffe, A. B., \& Stavins, R. N. (1994). The energy efficiency gap: what does it mean? Energy Policy, 22(10), 804-810.

Jakob, M. (2006). Marginal costs and co-benefits of energy efficiency investments. The case of the Swiss residential sector. Energy Policy, 34(2 SPEC. ISS), 172-187.

Katuwal, H., \& Bohara, A. K. (2009). Biogas: a promising renewable technology and its impact on rural households in Nepal. Renewable and Sustainable Energy Reviews, 13(9), 26682674.

Koornneef, J., van Keulen, T., Faaij, A., \& Turkenburg, W. (2008). Life cycle assessment of a pulverized coal power plant with post-combustion capture, transport and storage of $\mathrm{CO}_{2}$. International Journal of Greenhouse Gas Control, 2(4), 448-467.

Kraxner, F., Nilsson, S., \& Obersteiner, M. (2003). Negative emissions from BioEnergy use, carbon capture and sequestration (BECS) - the case of biomass production by sustainable forest from semi-natural temperate forests. Biomass and Bioenergy, 24(4-5), 285-296.

Lilly, P. \& Pearson, D. (1999). Determining the full value of industrial efficiency programs. Proceedings ACEEE Summer Study on Energy Efficiency in Industry, 349-362. 
Lumijärvi, O. P. (1991). Selling of capital investments to top management. Management Accounting Research, 2, 171188.

Lung, R. B., McKane, A., Leach, R., Marsh, D. (2005). Ancillary savings and production benefits in the evaluation of industrial energy efficiency measures. Proceedings ACEEE Summer Study on Energy Efficiency in Industry.

Malla, S. (2009). $\mathrm{CO}_{2}$ emissions from electricity generation in seven Asia-Pacific and North American countries: a decomposition analysis. Energy Policy, 37(1), 1-9.

Martinaitis, V., Kazakevičius, E., \& Vitkauskas, A. (2007). A twofactor method for appraising building renovation and energy efficiency improvement projects. Energy Policy, 35(1), 192201.

Mestl, H. E. S., Aunan, K., Fang, J., Seip, H. M., Skjelvik, J. M., \& Vennemo, H. (2005). Cleaner production as climate investment-integrated assessment in Taiyuan City, China. Journal of Cleaner Production, 13(1), 57-70.

Mills, E., \& Rosenfeld, A. (1996). Consumer non-energy benefits as a motivation for making energy-efficiency improvements. Energy, 21(7-8), 707-720.

Mills, E., Shamshoian, G., Blazek, M., Naughton, P., Seese, R. S., Tschudi, W., \& Sartor, D. (2008). The business case for energy management in high-tech industries. Energy Efficiency, 1(1), 5-20.

Mundaca, L. (2008). Markets for energy efficiency: exploring the implications of an EU-wide 'Tradable White Certificate' scheme. Energy Economics, 30(6), 3016-3043.

Nagesha, N. (2008). Role of energy efficiency in sustainable development of small-scale industry clusters: an empirical study. Energy for Sustainable Development, 12(3), 34-39.

Neves, L. P., Martins, A. G., Antunes, C. H., \& Dias, L. C. (2008). A multi-criteria decision approach to sorting actions for promoting energy efficiency. Energy Policy, 36(7), 23512363.

Nishioka, Y., Levy, J. I., Norris, G. A., Wilson, A., Hofstetter, P., \& Spengler, J. D. (2002). Integrating risk assessment and life cycle assessment: a case study of insulation. Risk Analysis, 22(5), 1003-1017.

Okoli, C., \& Schabram, K. (2010). A guide to conducting a systematic literature review of information systems research. Sprouts: Working Papers on Information Systems, 10(26), 149.

Paramonova, S., Thollander, P., \& Ottosson, M. (2015). Quantifying the extended energy efficiency gap - evidence from Swedish electricity-intensive industries. Renewable and Sustainable Energy Reviews, 51, 472-483.

Pye, M., \& McKane, A. (2000). Making a stronger case for industrial energy efficiency by quantifying non-energy benefits. Resources, Conservation and Recycling, 28(3-4), 171183.

Qiu, Y., Wang, Y. D., \& Wang, J. (2015). Implied discount rate and payback threshold of energy efficiency investment in the industrial sector. Applied Economics, 47(21), 2218-2233.

Rafaj, P., \& Kypreos, S. (2007). Internalisation of external cost in the power generation sector: analysis with global multiregional MARKAL model. Energy Policy, 35(2), 828-843.

Rypdal, K., Berntsen, T., Fuglestvedt, J. S., Aunan, K., Torvanger, A., Stordal, F., Pacyna, J. M., \& Nygaard, L. P. (2005). Tropospheric ozone and aerosols in climate agreements: scientific and political challenges. Environmental Science and Policy, 8(1), 29-43.

Sandberg, P., \& Söderström, M. (2003). Industrial energy efficiency: the need for investment decision support from a manager perspective. Energy Policy, 31, 1623-1634.

Sardianou, E. (2008). Barriers to industrial energy efficiency investments in Greece. Journal of Cleaner Production, 16(13), 1416-1423.

Sauter, R., \& Volkery, A. (2013). Review of costs and benefits of energy savings. Task 1 Report. IEEP. Brussels: IEEP for the Coalition of Energy Savings.

Schweitzer, M., \& Tonn, B. (2003). Non-energy benefits of the US Weatherization Assistance Program: a summary of their scope and magnitude. Applied Energy, 76(4), 321-335.

Singh, B., Strømman, A. H., \& Hertwich, E. G. (2012). Scenarios for the environmental impact of fossil fuel power: co-benefits and trade-offs of carbon capture and storage. Energy, 45(1), $762-770$.

Skumatz, L. \& Dickerson, C. (1997). Recognizing all program benefits: estimating the non-energy benefits of PG\&E's Venture Partners Pilot Program (VPP). 1997 Energy evaluation conference. Chicago.

Skumatz, L., Dickerson, C., Coates, B. (2000). Non-energy benefits in the residential and non-residential sectors - innovative measurements and results for participant benefits. Proceedings ACEEE Summer Study on Energy Efficiency in Buildings, 8353-8364.

Sorrell, S., Schleich, J., Scott, S., O’Malley, E., Trace, F., Boede, U., Ostertag, K., \& Radgen, P. (2000). Reducing barriers to energy efficiency in public and private organizations. Brighton: Energy research centre - science and technology policy research (SPRU), University of Sussex.

Thollander, P., \& Ottosson, M. (2008). An energy efficient Swedish pulp and paper industry - exploring barriers to and driving forces for cost-effective energy efficiency investments. Energy Efficiency, 1(1), 21-34.

Thollander, P., \& Ottosson, M. (2010). Energy management practices in Swedish energy-intensive industries. Journal of Cleaner Production, 18(12), 1125-1133.

Tonn, B., \& Peretz, J. H. (2007). State-level benefits of energy efficiency. Energy Policy, 35(7), 3665-3674.

Tranfield, D., Denyer, D., \& Smart, P. (2003). Towards a methodology for developing evidence-informed management knowledge by means of systematic review. British Journal of Management, 14, 207-222.

Trianni, A., Cagno, E., Thollander, P., \& Backlund, S. (2013). Barriers to industrial energy efficiency in foundries: a European comparison. Journal of Cleaner Production, 40, 161-176.

Trianni, A., Cagno, E., \& De Donatis, A. (2014). A framework to characterize energy efficiency measures. Applied Energy, $118,207-220$.

Ürge-Vorsatz, D., Harvey, L. D. D., Mirasgedis, S., \& Levine, M. D. (2007). Mitigating $\mathrm{CO}_{2}$ emissions from energy use in the world's buildings. Building Research and Information, 35(4), 379-398.

Ürge-Vorsatz, D., Novikova, A., Köppel, S., \& Boza-Kiss, B. (2009). Bottom-up assessment of potentials and costs of $\mathrm{CO}_{2}$ emission mitigation in the buildings sector: insights into the missing elements. Energy Efficiency, 2(4), 293-316. 
Venmans, F. (2014). Triggers and barriers to energy efficiency measures in the ceramic, cement and lime sectors. Journal of Cleaner Production, 69, 133-142.

van Vuuren, D., Fengqi, Z., de Vries, B., Kejun, J., Graveland, C., \& Yun, L. (2003). Energy and emission scenarios for China in the 21st century-exploration of baseline development and mitigation options. Energy Policy, 31(4), 369-387.

van Vuuren, D. P., Cofala, J., Eerens, H. E., Oostenrijk, R., Heyes, C., Klimont, Z., den Elzen, M. G. J., \& Amann, M. (2006).
Exploring the ancillary benefits of the Kyoto protocol for air pollution in Europe. Energy Policy, 34(4), 444-460.

Worrell, E., Laitner, J. A., Ruth, M., \& Finman, H. (2003). Productivity benefits of industrial energy efficiency measures. Energy, 28(11), 1081-1098.

$\mathrm{Xu}$, Y., \& Masui, T. (2009). Local air pollutant emission reduction and ancillary carbon benefits of $\mathrm{SO}_{2}$ control policies: application of AIM/CGE model to China. European Journal of Operational Research, 198(1), 315-325. 